\title{
Preserving the Nation's Zeal: Church Buildings and English Christian History in Stuart England
}

\author{
Anne-Françoise Morel
}

$1 \quad$ Introduction

Henry viII's break with the Roman Catholic Church not only created the National Church of England but left this newly established state Church with a historical vacuum. While the dissolution of monasteries and the iconoclastic 'cleansing' of churches took place in the first decades after 1534 and later during the Civil War, the establishment of a Church with firm English roots remained uncertain until the end of the seventeenth century. This situation had consequences for church architecture reaching well beyond iconoclasm. As the study of sermons preached upon the occasion of the consecration of churches during the Stuart period has demonstrated, the status, function, and architecture of the church building were heavily debated. ${ }^{1}$ After Henry vis I's break with Rome church historians started to rewrite the history of Christianity in England. But one had to wait until the seventeenth century for the discussion on the architecture of the church building as a dignified and monumental expression of the English Church. Only then did architects and theologians dig into antiquarian studies in order to define the status of and reflect upon the architecture of church buildings in the Church of England. The roots of the Church of England were established in biblical history, early Christianity, and England's Anglo-Saxon and medieval past, three major sets of referents which would also be materialized in various church-building projects, not least in the official church-building campaign of 1711.

Biblical and early Christian history played a fundamental role in establishing the historical lineage of the Church of England as stretching back to the very wellspring of Christianity. These references were part of a common set of referents shared by all Christian churches, reformed or not, and hence they

1 Morel A.-F., Glorious Temples or Babylonic Whores: The Architecture of Church Buildings in England 1603-1736 according to Consecration Sermons, $\mathrm{PhD}$ dissertation (Ghent University: 2011).

(C) ANNE-FRANÇOISE MOREL, 2019 | DOI:10.1163/9789004378216_026

This is an open access chapter distributed under the terms of the prevailing CC-BY-NC-ND License 
played a crucial role in (Counter-)Reformation historiography. ${ }^{2}$ Contrary to the early Christian and biblical referents, the Anglo-Saxon and medieval referents are genuinely English, a characteristic which was of crucial importance in the creation and legitimation of the Church of England as a national Church under royal supremacy, but which was equally problematic due to its associations with 'monkish popery'.

In this article I will demonstrate how patrons and architects intentionally engaged with historical and theological debates on church buildings in order to conceptualize their idea of the 'Anglican' church building and to translate these concepts into architecture. For this study I will use sermons, antiquarian tracts, and English church history. These writings gradually developed as an alternative to the classical - most often Italian and thus Roman Catholic - architectural treatises on the topic of church building. They informed patrons and architects and ultimately led to the development of theories and design practices on 'good' Anglican church buildings over the course of the seventeenth century.

\section{The Edification of the Church of England}

Between 1679 and 1715, Richard Burnet published The History of the Reformation of the Church of England, for many years the classic tale of the history of the Church of England. The first volume, published in 1679, charts the start of the Reformation under the reign of Henry VIII (r. 1509-1547) almost 150 years earlier. Central to Burnet's text is the historical legitimation of the English Reformation, namely the legacy and restoration of the pure primitive Church. Against the background of this argument, it is the frontispiece of the book which retains my interest for the present study.

The frontispiece, designed by Robert White [Fig. 24.1], portrays the 'architects' of the English Reformation: Henry VIII and Thomas Cranmer (14891556). Behind Henry VIII and Cranmer there are two church buildings. The building closest to the monarch, which is being torn down, represents the superstition of the Roman Church, while the other building behind Cranmer represents true religion and the Reformed Church of England, which is in full construction. Hence the new building also materializes the Covenant established between the English nation and God.

2 Delbeke M. - Morel A.-F., "Metaphors in Action: Early Modern Church Buildings as Spaces of Knowledge", Architectural History 53, 10 (2010) 99-122. 


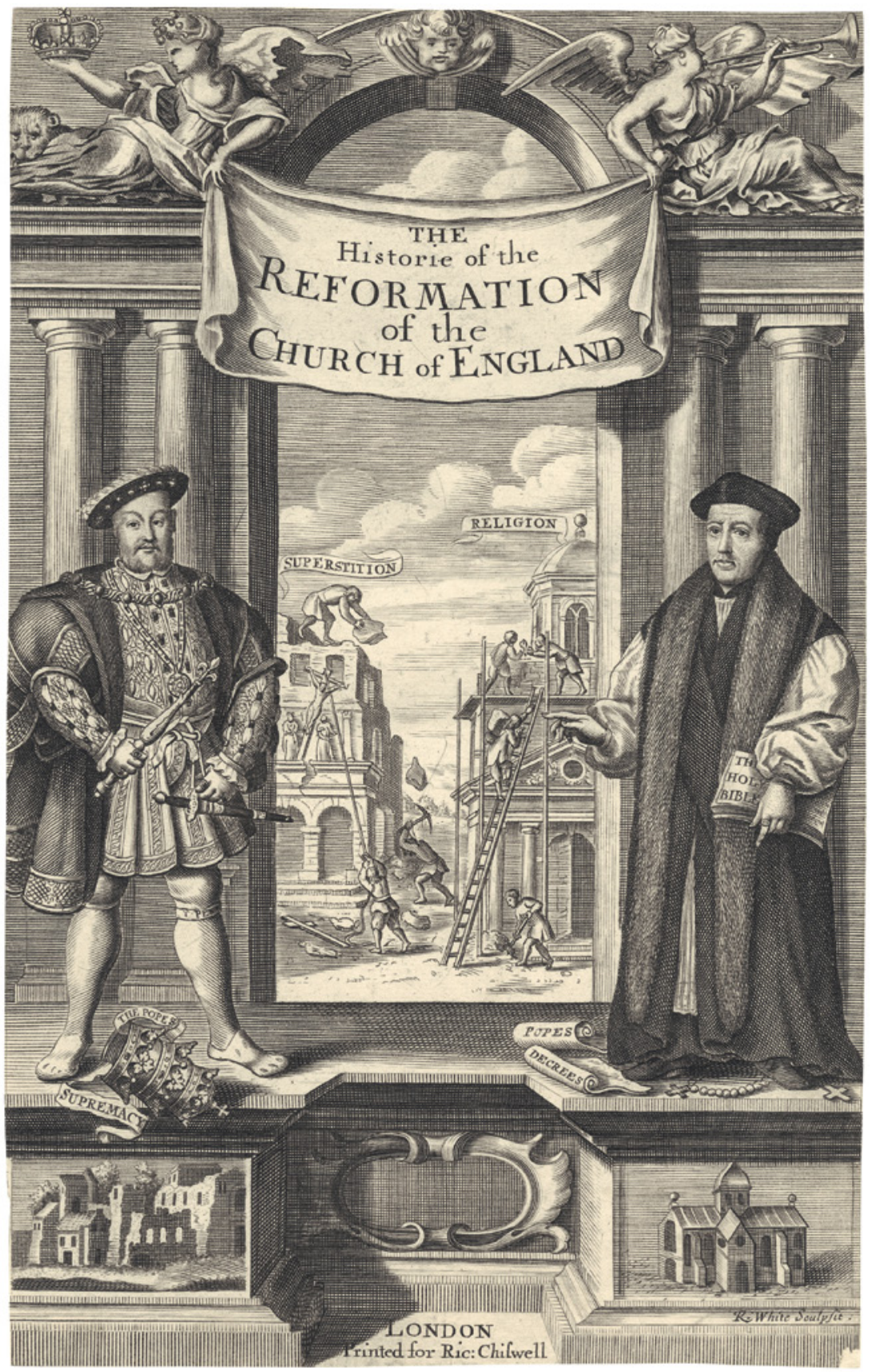

FIGURE 24.1 Robert White, Henry viII and Thomas Cranmer. Frontispiece engraving to Richard Burnet, A History of the English Reformation [...] (London: 1679) IMAGE (C) LONDON, NATIONAL PORTRAIT GALLERY 
The use of an architectural metaphor in the frontispiece of a book devoted to English Church history is not unusual. It was normal for seventeenth-century authors to design their title pages as a visual statement of the argument of their book. The English antiquary William Dugdale (1605-1686), who was influential in medieval studies, also used explicit architectural references for the title page of his Monasticon Anglicanum, a book describing the history of religious institutions and buildings in England [Fig. 24.2]. Central is the theme of the sanctity of religious endowments, illustrated on the left plinth by a medieval king making an act of donation to an abbey and at the top left an abbey, possibly Glastonbury. According to medieval and early modern Christian history, Glastonbury was founded in the first century by Joseph of Arimathea. The site not only functioned as an expression of the piety of the early Church but even more so as proof of the early Christian roots of the Church of England. At the bottom right stands Henry VIII reneging on his predecessors' vows and piety at the Dissolution of the monasteries. ${ }^{3}$

Regardless of the political and religious context in which they were printed (the first one during the Restoration and the second one 30 years before, during the Commonwealth), both frontispieces seem to link the history and the establishment of the Church of England to the buildings of this Church: the first one is referring to Burnet's church history, the second to Dugdale's Monasticon. In other words, they recognize the monumental value of architecture. As Caroline van Eck has demonstrated in her analysis of Henry Wotton's The Elements of Architecture (1624) and Christopher Wren's Notes on architecture of 1670 , there was a strong sense of the monumental value of architecture in seventeenth-century England, probably enforced not only by the international circulation of architectural treatises, but even more so by the iconoclastic waves of the sixteenth-century Reformation and the Civil War: Monuments represented by conjuring up images and emotions stored in memory. ${ }^{4}$

As the above-mentioned title pages and the examples used in this article will make clear, this monumental value was closely related to the development of a discourse on the history of church architecture in England. Contrary to what the iconoclastic movements and the earliest guidelines on church architecture might induce, both the historical value and the monumental value played a very important role in the development of the church-building practice in

3 Parry G., The Trophies of Time: English Antiquarians of the Seventeenth Century (Oxford: 1995) 231-233.

4 Eck C. van, Classical Rhetoric and the Visual Arts in Early Modern Europe (Cambridge: 2007) 96. 


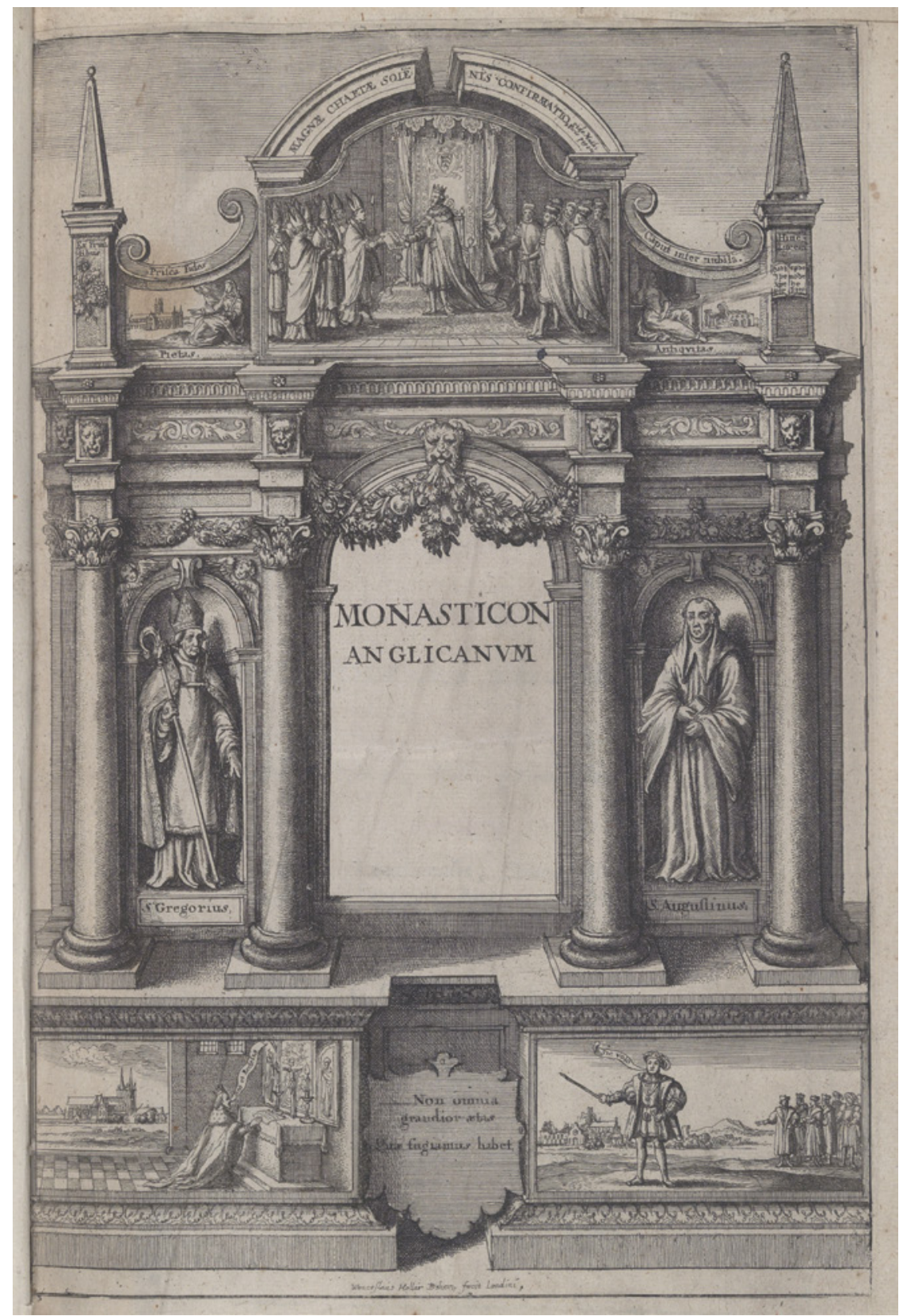

FIGURE 24.2 Wenceslaus Hollar, "The sanctity of the religious endowments". From: William Dugdale, Monasticon Anglicanum [...] (London, Richard Hodgkinson: 1655-1673)

IMAGE (C) GHENT UNIVERSITY LIBRARY 
Stuart England, eventually culminating in the Commission for the Building of Fifty New Churches, launched in 1711 by Queen Anne.

The study of the history of Christianity played an important role from the earliest years of the Reformation in the Church of England, but it was not until the seventeenth century that it was used in debates on church architecture. Looking at the official guidelines of the State Church - leaving aside the extreme iconoclastic decisions taken during the Civil War and the Interregnum - the subject of 'reformed' church architecture was only explicitly addressed in the Second Book of Homilies, published under Elizabeth I, with a particular emphasis on ornamentation and image worship instead of on the building itself. The two homilies related to the fabric and decoration of the place of worship are entitled For repayring and keeping cleane, and comely adorning of Churches and Against perill of Idolatrie, and superfluous decking of Churches. Their major concern is that the churches be cleansed and purged from 'superstition, hypocrisie, false worship, false doctrine, and insatiable covetousnesse', from the expressions of 'worldly and vaine religion, in phantasticall adorning and decking. ${ }^{5}$ The 'house of GOD, which wee commonly call the Church', must be 'sufficiently repayred in all places, and [...] honourably adorned and garnished', ${ }^{6}$ 'with places convenient to sit in, with the Pulpit for the preacher, with the Lords table, for the ministration of his holy supper, with the Font to Christen in. ${ }^{7}$ Ornaments are considered as being contrary to purity and sincerity.

These texts were written during the Elizabethan Settlement and consequently are based on the fundamental sixteenth-century concepts of the dichotomy between true and false religion: There was a clear attempt to distinguish the humility, simplicity, purity, and order of the godly from the pride, pomp, circumstance, chaos, and worldly desires of the ungodly. ${ }^{8}$ The question remained as to how to define and express in architecture what good, true, and pure would be without falling into the extremes of idolatry, iconoclasm, and

5 Jewel John, "Against Perill of Idolatrie, and Superfluous Decking of Churches" and "For Repayring and Keeping Cleane, and comely adorning of Churches" in Jewel John (ed.), The Second Tome of Homilies [...] Set Out by the Authority of the Late Queens Majestie: and to be Read in Every Parish Church Agreeablie (London, John Bill: 1623) 11-76 and 77-81, here 80.

6 Jewel, "For Repayring and Keeping Cleane" 77.

7 Ibidem 80.

8 Davies C., A Religion of the Word: The Defence of the Reformation in the Reign of Edward VI (Manchester: 2002) 22-25. 
heresy, a delicate exercise which would be of great concern for all forthcoming church-building activity in the seventeenth century. ${ }^{9}$

\section{$3 \quad$ Building the True and Primitive Church}

Lancelot Andrewes (1555-1626) - Church of England clergyman and divine scholar - defined the sources of the Church of England in a sermon preached before James I. They included Scripture and the first six centuries of Christianity: ${ }^{10}$

One canon of Scripture which we refer to God, two Testaments, three Creeds, the first four Councils, five centuries and the succession of the Fathers in these centuries, three centuries before Constantine, two centuries after Constantine, draw the rule of our religion. ${ }^{11}$

Hence, the first texts in seventeenth-century England to deal with the subject of the church building constantly refer to the Bible and to Christian traditions, especially the first two centuries after Christ until time of Constantine the Great. The leading topographical and typological themes are the Tabernacle, the Temple, public worship under primitive Christianity, and the magnificent churches of Constantine. The primacy of Scripture and the early Fathers was fundamental in the establishment of the Church of England and remained an absolute authority. ${ }^{12}$ Most of these texts were religious pamphlets, theological tracts, and sermons published in the 1630s, in the midst of the religious reforms conducted by Archbishop William Laud (1573-1645), who strove for a highly ceremonial and ritualistic form of worship, which resulted in ornamental

9 It is commonly assumed that almost no church-building activity took place under the reign of Elizabeth. Hence Bishop King's commission to Anthony Munday to write a continuation of Stow's Survey of London. It was the bishop's aim to give an overview of the revival in church refurbishment in the capital in order to serve as answer to the Roman Catholic attacks. Merritt J.F., "Puritans, Laudians, and the Phenomenon of ChurchBuilding in Jacobean London", The Historical Journal 41, 4 (1998) 938-939.

10 During James I's reign Andrewes became bishop, a position which would give him a leading role in the Church and make him a model in the decades to come. James I never made him archbishop because of Andrewes' ceremonialist preferences.

11 Andrewes Lancelot, quoted in: Quantin J.L., "The Fathers in Seventeenth Century Anglican Theology", in Backus I. (ed.), The Reception of the Church Fathers in the West: From the Carolingians to the Maurists, 2 vols. (Leiden: 1997), vol. 2, 989.

12 Morel, Glorious Temples chapter 2; Delbeke - Morel, "Metaphors in Action" 99-122. 
church architecture based upon tradition..$^{13}$ Whether they were written by Laudian partisans or opponents, their sources, references, and topics are the same. The authors discuss the apostolic foundation of the church building, the rituals surrounding the building, and its status, as well as practical concerns regarding the liturgical space, the decoration of churches, and the placement of church furniture, within a historical sequence of biblical, early Christian, and sometimes Anglo-Saxon traditions. The organization of the liturgical space excepted, the architecture of the church building is never discussed, and attention to the building's style does not seem to have been maintained. The most important concern was to ground the church building in the religious and liturgical practices of the 'true' Church. ${ }^{14}$

The Bible and early Christian tradition were a powerful source for thought about architecture, not only because of the descriptions of Solomon's Temple and Constantine's churches, but even more so because of the conflicting images these models presented about the moral value of the act of building. Magnificent church buildings, as expressed in Solomon's Temple or Constantine's churches, were approved as a way of praising God, but they were also rejected as an unjustified indulgence in materialism and luxury, most often exemplified by Herod's reconstruction of the original Temple. ${ }^{15}$ At the consecration of the parish church in Flixton (1630), the Calvinist Brinsley condemned the richness of Herod's Temple as a work of Satan which diverted worshippers' thoughts by means of external beauty:

That the eyes of the Jewes be dazled with this outward pompe and glory they might looke no further, but that their thoughts might hereby be wholly taken off from looking for, or longing after the promised Messias.

13 On Laud and church building, see Fincham K. - Tyacke N., Altars Restored: the Changing Face of English Religious Worship, 1547-c.170o (Oxford: 2007); Parry G., Glory, Laud and Honour: The Arts of the Anglican Counter-Reformation (Woodbridge: 2006).

14 Major texts are: Pocklington John, Altare Christianum: Or, the Dead Vicars Plea: Wherein the Vicar of Gr. being dead, yet speaketh, and pleadeth out of antiquity, against him that hath broken downe his Altar (London, Richard Badger: 1637); Mede Joseph, Churches, That Is, Appropriate Places for Christian Worship. Both in, and Ever since the Apostles Times (London, M.F. for John Clark: 1638); R.T., De Templis, a Treatise of Temples, Wherein is discovered the ancient manner of building, consecrating and adorning of churches (London, R[ichard] Bishop: 1638); and Robartes Foulke, Gods Holy House and Service, According to the Primitive and Most Christian Forme (London, Thomas Cotes: 1639).

15 van Eck C., British Architectural Theory 1540-1750: An Anthology of Texts (Aldershot: 2003) 104-105; Morel, Glorious Temples. 
And if so, then was this cost bestowed upon this last Temple, rather a profanation then an adorning of it. ${ }^{16}$

For other churchmen, the Temple and churches built by Constantine were commonly used as examples for stately and magnificent architecture, built in accordance with God and during periods when religion was still pure and exemplary.

Hence, religious history and controversy gradually forced churchmen to establish the underlying principles of ecclesiastical architecture not in terms of style but in terms of the particular status of the building as a built testimony to the Church of England and its long-standing uncorrupted Christian tradition. This initially resulted in what one could call the first treatise on church architecture in England - R.T.'s De Templis - and would be of tremendous importance for the church-building activity of the Restoration Church.

R.T.'s De Templis. A Treatise of Temples. Wherein is discovered the Ancient manner of Building, Consecrating and Adorning of Churches was anonymously published in 1638 for the praise of the restauration campaign of St Paul's Cathedral by Inigo Jones as well as in defence of the Laudian policy. Referring to biblical and Christian tradition since ancient times, the author pays a lot of attention to the necessity of building churches and providing them with sufficient ornamentation in order to express both the piety of the devotee as well as God's magnificence. He also discusses the liturgical origins of the different forms of ground plans used in churches over time, with reference to the Bible (Temple of Solomon), the Church Fathers, and the canonist and liturgical writer Durandus (ca. 1230-1296), who offered a symbolical and liturgical interpretation of the church building in his Rationale Divinorum Officiorum (1286). In his last chapter, $A$ decent forme of building and adorning a Church, R.T. combines the lessons from the historical examples with the liturgical requirements of the (Laudian) Church of England. He prefers a basilical plan to a central one. Although the latter might be more convenient for hearing sermons, the longitudinal plan enhances the

Majesty and the reverence of the Place. [...] And the man who enters the West doore from farre beholding the Altar where he seriously intends to

16 Brinsley John, The Glorie of the Latter Temple Greater Then of the Former. Opened in a sermon preached at the consecration or restitution of the parish church of Flixton [...] 11. March. 1630 (London, for Robert Bird: 1631) 12. 
offer his devotions to his God and Saviour, shall find his devout soule, more rapt with divine awe and reverence, more inflamed with pure and holy zeale, in the delay and late approach unto it, than if at first he had entered upon it. ${ }^{17}$

Pillars are required to separate the nave from the aisles, and according to the building tradition of the primitive Christians, chancel screens should separate the quire from the body of the church

The Chancell being divided from the Church by grates of wood, curiously carved, or of iron, or brasse cast into comly works, is not onely very gracefull, but according to the lawes and orders of building observed by the primitive Christians. ${ }^{18}$

Referring to the same primitive Christians, R.T. is in favour of a crypt underneath the quire. Regarding the architecture of the church building R.T. does not refer to historical sources, as according to him the architecture and the style of the building are only subject to the fashions of time: "The externall forme, of which wee intend to speak, depending almost wholly on the fancie of the Architect, has ever been various, and uncertaine.' ${ }^{19}$ This does not, however, mean that the architecture of the church building is of no importance. On the contrary, De Templis is a - for that time very exceptional - exposition of the ways in which the architecture of the church building can direct the religious experience and how the architecture adds to the building's character. ${ }^{20}$

For Parish Churches, and private Chappels, it were very meet that they should be built after the manner of Cathedrals, as neere as with convenience they may. When there are no Iles adjoyning to the body of the Church, Pilasters wrought into the wall, with well framed Capitals, would adde much beauty to the fabrique, and much strength to the wals, between which would bee convenient spaces to beautifie the Church, with some excellent paintings of Sacred stories, which may strike into the beholder, religious, and devout Meditations. Over the Capitals according to the common rules of Architecture, must run an Architrave freeze, and Coronis, which every work-man knowes how to adorne with leaves

17 R.T., De Templis 190-191.

18 R.T., De Templis 193.

19 R.T., De Templis 38-39.

20 van Eck, British Architectural Theory 123. 
and flowers, etc. according to the order of building [...]. The roof if it be vaulted, is more agreable to antiquitie, than if flat, it makes the voyce more audible; you may adorn it with an azure colour, and gilded starts and then as in figure, so in colour it resembles the Hemisphear of the Heavens; which perhaps gave occasion to S. Chrysost: to cal the Church oupavòv ह่ $\pi i \gamma \varepsilon ı$, an earthly heaven. ${ }^{21}$

Regardless of historical models, and in compliance with Inigo Jones' recent intervention at St Paul's Cathedral, R.T. favours classical architecture. ${ }^{22}$

R.T. does, however, use a particular English form of religious architecture, in casu the preaching cross, to establish a historical connection between early Christianity and church building in England and the earliest biblical traditions found in the Old Testament. R.T. roots the erection of preaching crosses in a Saxon building practice, which was itself based on the Old Testament's figure of the holy pillar.

It is reported of our own Ancestors the old Saxons, that they used to have publique praiers under a Crosse, erected in the open fields, which place and structure was to them a Temple [...] We read also how the holy Patriarch Iacob, erected the stone on which he had slept, for a Temple $[\ldots] .{ }^{23}$

By using this reference, R.T. brings in another set of historical referents, namely the English early Christian tradition or the Anglo-Saxon tradition, in the discourse on church building. Anglo-Saxon references had been used since the Reformation in order to refute papal authority in the establishment of Christianity in England. However, it was only in the seventeenth century through the successive re-editions of William Camden's Brittania (1586-1607), Richard Vestegan's study A Restitution of Decayed Intelligence in Antiquities (1605), and most importantly James Ussher's A Discourse of the Religion

\footnotetext{
$21 \quad$ R.T., De Templis 194-195, 198.

22 De Templis is dedicated to Sir John Pindar, who contributed the enormous sum of £10,000 towards the rebuilding of St Paul's Cathedral. See: http://www.vam.ac.uk/content/ articles/s/sir-paul-pindars-house/, accessed on 27 February 2017. 
anciently professed by the Irish and the British (1626) - that Anglo-Saxon antiquity forged ahead in ecclesiastical history. All of the authors concluded that for all their initial barbarism, the Saxons had been the people who had contributed most decisively to the formation of the English identity by means of language, religion, and, last but not least, the establishment of a comprehensive network of churches and monasteries by the end of the eighth century. ${ }^{24}$ The conviction existed that the planting of the Church in England occurred in apostolic times and that its primitive force and independent constitution had continued uninterruptedly from Romano-British to Saxon times. Hence, in 1638 , the same year as the publication of R.T.'s De Templis, the antiquarian Sir Henry Spelman established the first Anglo-Saxon lectureship at the University of Cambridge for the study of 'domestic antiquities touching our church'.

This driving force in establishing the historical roots of an English Church based on both international and genuine English referents was abruptly changed during the Civil War and Interregnum. Church history and Saxon antiquity no longer served as an argument in theological debates regarding the origins and the traditions of the Church of England, but instead became fundamental for the safeguarding of the English Church as antiquarian studies started to play an important role in maintaining the Church's position within English society. The antiquarians - who admittedly had often been sympathetic to the Laudian policy, as their care for the material well-being of the Church and its traditions inclined them towards being sympathetic to Laud's efforts to heighten the sacredness of the Church and to dignify and embellish the church as a place of worship - linked the moral and architectural decline of the English nation in the 1640 s and 1650 s. For the antiquarians, the churches and their monuments, regardless of the period in which they were built, were the visible testimony to the nation's Christian history and zeal. Hence William Dugdale, to give one of the most famous examples, undertook his study on St Paul's Cathedral (1655) incited by the demolitions of the Civil War. The Puritan party deemed ornaments, images, stained-glass windows, and monuments to be trappings of popery. Even cathedrals themselves, as the seats of the hated bishops, came under threat. These records of stone, glass, and brass were the working stock of the antiquarians, and they were imminently threatened with destruction. ${ }^{25}$ Through his antiquarian work Dugdale hoped to preserve a testimony to the religious monuments, so that future generations could

24 Parry, The Trophies of Time 37.

25 Parry, The Trophies of Time 221. 
retrieve not only an architectural description of the Old St Paul's, but even more so the religious zeal of the nation from before the Civil War!26

For all the attention he paid to St Paul's and the other English cathedral churches, Dugdale never mentions any architectural detail in his texts. The monumental quality (monumental as referring to both the commemorative function and the imposing character of the architecture) of the church buildings was, however, present in the rich illustrations accompanying the text. These illustrations gained importance in the re-editions after the Restoration. For instance, a new edition of Dugdale's history was reprinted in 1664 with engravings by Daniel King and Wenceslaus Hollar. Of particular interest are Hollar's etchings of the interior of what Dugdale calls the 'Stupenduous Basilica' [Fig. 24.3]. These etchings do not show all the statues, altars, liturgical utensils, etc., that would have adorned the interior until the 1640 s, but instead depict vast empty spaces. This monumental vastness of the cathedral space evoked awe and religious majesty rather than the earlier ambivalence towards the general desolation of monastic and ecclesiastical ruins as residues of the former Roman Catholic idolatry. Dugdale's case was no exception. ${ }^{27}$ The antiquarian discourse showed a historical interest and a religious concern, emphasizing how the church building had been part and parcel of (medieval) piety and devotion to the glory of God and the English nation since the earliest establishment of Christianity in England. Indeed, for many early antiquarians, the building of churches remained primarily an act of piety and devotion instead of an act of architecture. Central in their texts was the monumental quality of the church building as a testimony to God's presence upon earth and as a monument of the zeal of the Godly elect nation of England. Deliberately masking and suppressing the desolate state of some of the depicted churches as scars of iconoclastic cleansing and purging, the etchings mostly strived towards a rehabilitation of the church building as a monument for the National Church of England.

The only antiquarian warning against the 'rehabilitation' of medieval church buildings was Thomas Fuller (1608-1661), a churchman with a mild Calvinist view. As a reaction to both the destruction of the Civil War and the views expressed by his fellow antiquarians, Fuller warned against the dangers of nostalgia facing medieval ruins. According to Fuller, the antiquary must be cautious

26 Dugdale William, The History of St. Pauls Cathedral in London from Its Foundation Untill These Times: Extracted out of originall charters, records, leiger books, and other manuscripts: beautified with sundry prospects of the church, figures of tombes and monuments (London, Thomas Warren: 1658). 


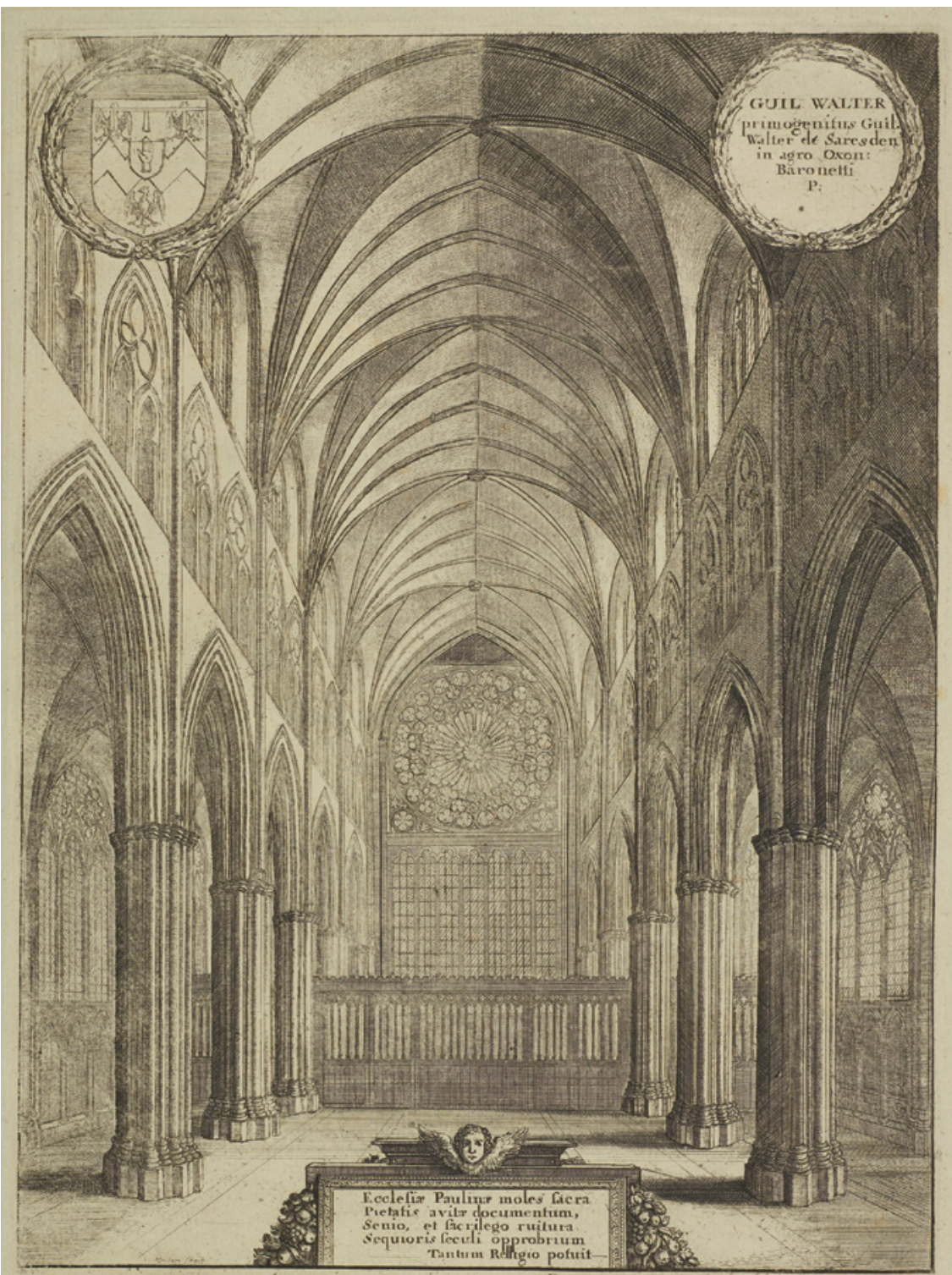

ORIENTALIS PARTIS ECCL: CATH: S: PAVLI PROSPECTVS INTERIOR

FIGURE 24.3 Wenceslaus Hollar, "Interior view of St Paul's Cathedral's east end, with coat of arms and description in medallions at top". From: William Dugdale, The History of St Pauls Cathedral in London (London, Thomas Warren: 1658) IMAGE (C) LONDON, METROPOLITAN ARCHIVES, MAIN PRINT COLLECTION 
not to develop any sympathy with the Church of the Middle Ages through the contemplation of monastic ruins. These ruins should rather remind him of the decay of the monks' religious life. However, his view remained an exception within the antiquarian movement. Church Antiquarianism

Whether it was driven by a preservationist and royalist attitude facing iconoclasm and war damage, or the profound will to trace the roots of the Church of England, the Anglo-Saxon and antiquarian movements showed an increasing interest in the medieval architecture of English churches and monasteries, as these buildings often testified to a continual lineage from Saxon foundations through to the recent past. Most antiquarians no longer viewed monasteries as places of ignorance and superstition but as centres of piety and learning. Their buildings became material testimonies of a complex social apparatus based upon highly evolved administrative systems as well as the product of a devotional movement that had no parallel in the Reformed world. Their destruction was felt as a void, which nothing had filled.28

The first to trace this historical lineage and evolution of Christian tradition in the architecture of a church building was William Somner (1598-1669).

He lov'd much, and much frequented the Cathedral service; where after his devotions were paid, he had a new zeal for the honour of the House, walking often in the Nave, and in the more recluse parts, not in that idle and inadvertent posture, nor with that common and trivial discourse, with which those open Temples are vulgarly profan'd: but with a curious and observant eye, to distinguish the age of the buildings [...]. His visits within the City were to find out the Ancestors, rather than the present inhabitants; and to know the genealogie of houses, and walls, and dust $[\ldots]$, the Saxon Monasteries and the Norman Churches. ${ }^{29}$

28 Parry, The Trophies of Time 10-11.

29 White Kenneth, "The Life of Mr. Somner", in Somner William, A Treatise of the Roman Ports and Forts in Kent [...] to which is prefixt the Life of Mr. Somner (Oxford, University Press: 1693) 1-118, here 9-10. 
In his work on Canterbury, Somner traces the history of Canterbury from Saxon through medieval to contemporary times, thus establishing one historical lineage, testified in the architecture of the building.

Somner was one if not the most proficient Anglo-Saxonist of his time. His High Church antiquarianism was supportive of the Laudian movement and of the privileges of the Church and the clergy. In his work on Canterbury Cathedral, Somner explicitly links the uninterrupted Christian history of Canterbury from 'the conversion of the English to Christianitie, [when] the prime Episcopall See was fixed at Canterbury' until the present day by combining traditional antiquarian evidence, such as tithes, endowments, and charters with 'the historie of the Churches Fabrick', or the consecutive building campaigns of the cathedral. ${ }^{30}$ By doing this he tries to work out the chronology of the building by references to stylistic change. For instance, quoting William of Malmesbury he states that most Saxon monasteries were built of wood, and that the Saxons were not able to raise arcades or arches in two or three tiers, a practice which was later introduced by the Normans. This practice of building arches or vaults of stone even left traces in the names of certain buildings, such as St Mary le Bow or Stratfort le Bow. ${ }^{31}$ The use of the architecture as a historical document or proof enables Somner to rectify some historical errors. Describing, for instance, St Michael's chapel, Somner is forced to conclude that this chapel was built much more recently than normally assumed:

A Chapell indeed in name old. For Archbishop Langton in Hen. 3 dayes is storied to have been there intombed. But the work of the building of the modern Chapell will not beare that age. I am therefore perswaded that the old one was fain to be taken down, whilest the body and crosse Iles of the Church were in building, to give better way to that work $[\ldots] .{ }^{32}$

Thanks to the attention he pays to the architectural history of the church, each building campaign is linked to the renewal of dedications, charters, and gifts. Hence architecture, piety, and Christian history become intrinsically linked. ${ }^{33}$ Furthermore, Somner's architectural analysis also allows him to understand the building's historical changes in terms of style and architectural effect,

3o Somner William, The Antiquities of Canterbury, or, a Survey of That Ancient Citie, with the Suburbs, and Cathedrall: Containing Principally Matters of Antiquity in Them All: Collected Chiefly from Old Manuscripts, Lieger-Bookes, and Other Like Records, for the Most Part, Never as yet Printed (London, J[ohn] L[egat]: 1640) 150.

31 Somner, The Antiquities 156-157, 168.

32 Somner, The Antiquities 168.

33 Somner, The Antiquities 158. 
hence making him appreciative of the beauty of Canterbury's architecture: 'the chiefest glory both of the City and my present survey thereof'. ${ }^{34}$

Through their studies, antiquarians like Dugdale and Somner developed a particular sensitivity toward the history of church building and its architecture. Firstly, in their view the history, beauty, and number of churches built over the centuries in England were testimonies of a continuous demonstration of public zeal. The recovery of antiquities and their monumental quality reflected glory upon the nation's past and future identity and religion. Consequently, contrary to all the abuses which had taken place in the late medieval Church, the cathedrals and churches built in that period could still be considered a product of zeal. The medieval constructions were considered as part of a longstanding evolution in church architecture going back to the earliest Christian foundations in England.

Hence, when describing the ruins of the religious past and when confronted with the iconoclastic outbreaks of the Civil War, the antiquarians were driven by a sense of loss. The physical and institutional break with the past had the dangerous potential to permanently wipe out a whole section of religious life. History had to be rewritten to suit the profound reshaping of the Church, and the events of the present helped to heighten contemporary consciousness of historical change. The visible rupture with the past prompted a passionate urge to preserve, as well as to straighten out the sequence of history. In his posthumously published The History of the Churches in England (1712) the antiquarian Thomas Staveley ( $\dagger 1683$ ) exemplifies this feeling with the case of Holy Trinity, Staunton Harold, rebuilt in 1653 by the local nobleman Robert Shirley. According to Staveley Holy Trinity was indeed a real bulwark of true (High Church) religion built during the Puritan Commonwealth. ${ }^{35}$ In his account Staveley describes the Gothic architecture of the building dating from 1650 as 'compleat for the Workmanship; plentiful and honourable for the Furniture, Ornament and Endowment'. ${ }^{36}$ He particularly praises Shirley as

34 Somner, The Antiquities 150.

35 Not only does Staveley give an overview of the earliest Christian foundations in England as he states in his introduction to the reader, he especially attempts to draw a comparative chronology and analysis of Saxon and Norman architecture in an evolutionary perspective: 'An account of the Time and Manner of Building and Endowing these ancient and venerable structures: Where may be observed, the Difference between the Saxon and the Norman Architecture; and what vast Disproportion in Process of Time, appear'd between the First poor Church at Glastenbury, and our now Magnificent Cathedrals'. Quoted from Staveley Thomas, The History of Churches in England, Wherein is shewn, The Time, Means and Manner of Founding, Building, and Endowing of Churches, Both Cathedral and Rural (London, J. Downing: 1712) ii.

36 Staveley Thomas, The History of Churches in England 144-145. 
'Heir and Ancestor of Hereditary Devotion and Loyalty' - corresponding to his perception of the building in the years after the Restoration, when Holy Trinity church was decorated by Shirley's son with a (Baroque!) inscription above the building's entrance: 'When all things sacred were throughout the Nation, were either Demolish'd or Profaned, Sir Robert Shirley Baronet founded this Church. Whose singular Praise it is, To have done the best things in the Worst Times, And Hoped them in the most Calamitous. The Righteous shall be had in everlasting Remembrance. ${ }^{37}$

Hence, from the Restoration onwards, the Anglican Church considered church buildings as contributing to the glory of the nation, as the buildings acted as an expression of the nation's Christian state. Following the antiquarian tradition, national strength was represented as based on the state Church embodying unity and stability from early Christianity until well into the 17th and 18th centuries. Certainly, in the High Church model of the 1670s the years of the Civil War and the Commonwealth and the Puritan forces behind them were associated with schism and rebellion. ${ }^{38}$

The architectural models thus were still firmly rooted in tradition. The biblical and early Christian models continued to inspire many projects, including St Peter's Cornhill in London (1681). William Beveridge, clergyman and church historian, emphasized the liturgical importance of chancel screens in his 1681 opening sermon of the said parish church:

Hence that place where this sacrament is administred, was always made and reputed the highest place in the Church. And therefore also, it was wont to be separated from the rest of the church by a Skreen of Network, in Latine Cancelli; and that so generally, that from thence the place its self is called the 'Chancel'. That this was anciently observed in the Building of all considerable Churches [...] within few centuries after the Apostles themselves, even in the days of Constantine the Great, as well as in all Ages since, I could easily demonstrate from the Records of those Times. ${ }^{39}$

37 National Trust, History of Staunton Harold Church, https://www.nationaltrust.org.uk/ staunton-harold-church/features/the-chapel-of-the-holy-trinity-at-staunton-harold, last view 3 January 2018. Inscription cited from Staveley, The History of Churches 144.

38 Quantin J.L., The Church of England and Christian Antiquity: The Construction of a Confessional Identity in the 17th Century (Oxford: 2009) 285-290.

39 A Sermon Concerning the Excellency and Usefulness of the Common-Prayer. By William Beveridge, D.D., Rector of St. Peter's Conhil, London, at the Opening of the said ParishChurch, the 27th of November, 1681. Now Lord Bishop of St. Asaph (12th ed., London, H[enry] Hills: 1708) 18. 
Under the antiquarian influence, some fervent High Church and royalist partisans even went so far as to present the 'Gothic' or traditional late medieval style as most appropriate for church buildings, since it was the result of an architectural evolution from the Anglo-Saxon past to the Middle Ages, with material testimonies still standing in the present day.

Even if this appreciation of the 'Gothic' was far from general - since a large body of Protestants in 1640 s and 1650 s still associated medieval architecture with monastic corruption and luxury - it would influence some new churchbuilding projects. ${ }^{40}$

Browne Willis, author of A Survey of the Cathedrals of York, Durham, Carlisle, Chester, [...] (1727), enthusiastically raised funds and conducted construction projects for several churches in his county. In 1704-1709, he restored St Mary's Bletchley to honour the memory of his parents. Characteristically for the ecclesiastical antiquarian thinking of the period, rather than lavishing money on 'Marble statues or fine Embellishments, whilst the other part of God's house in which they lay wanted both a Requisite Decency and convenience for His Worship', ${ }^{41}$ he repaired the whole church instead. The pinnacle of this attitude, which would have pleased more than one High Church Anglican antiquarian, was reached with the complete rebuilding of St Martin's Church, Fenny Stratford [Fig. 24.4], between 1724 and 1730, which was done in memory of Willis' grandfather, the physician Thomas Willis. Here, Willis' love of architecture was combined with his antiquarian background and with a forthright rejection of religious nonconformity. Willis instructed the architect-builder Edward Wing (replaced by John Simmonds in 1728) to use the Gothic style, albeit of a kind that owed more to the medieval past than the playful 'gothick'

40 Parry points to the fact that this appraisal of monastic and medieval architecture was far from general. A large body of Protestant believers in 1640s and 1650s England held the opinion that medieval monasticism was a totally corrupt form of religious life, one marked by laziness and expressed, among other ways, in luxurious architecture. For them the monastic ruins were not a sad testimony to a breach in nation's zeal since early Christianity, but on the contrary 'the most visible reminder of the Reformation that had created modern England and that had given Protestant Englishmen their identity: they acted as markers that differentiated the old order from the new. The upholders of the new order, the Protestant gentry, did not want any formidable reminders of the Catholic past nor did they wish to have a printed record of titles to their estate before the Dissolution, for so many of them had benefited from that change'. See Parry, The Trophies of Time 227. Bodl. Oxf., MS Willis 2, fol. 99, quoted from Dogett Nicholas, "Willis Browne (1682-1760) Antiquary", in Oxford Dictionary of National Biography Online (2009), doi.org/10.1093/ ref:odnb/29577. 


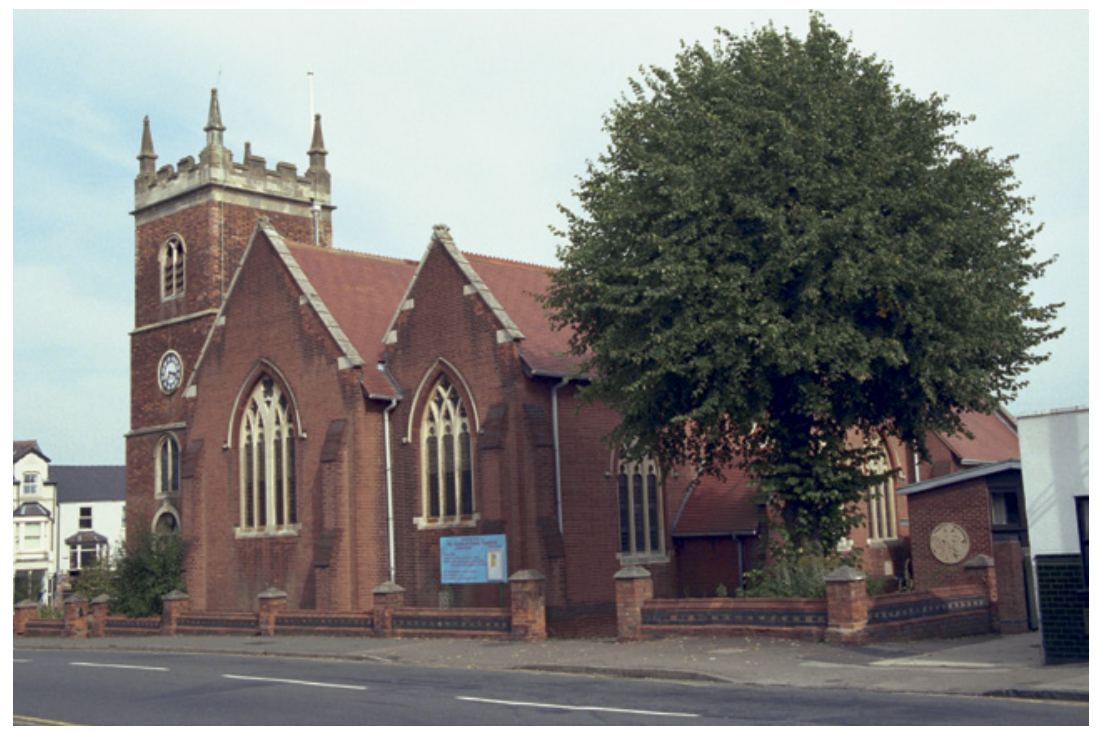

FIGURE 24.4 St Martin's Church, Fenny Stratford (1724-1730), John Simmonds IMAGE () HISTORIC ENGLAND ARCHIVE (NATIONAL HERITAGE, IMAGES OF ENGLAND. NICK JARVIS)

elements which were becoming typical of the churches of Hawksmoor and Vanbrugh at this time. ${ }^{42}$

Lord Digby, who sponsored the construction of the church of St Mary Magdalene in Sherbourne (1715) [Fig. 24.5], also favoured the Gothic design which was a continuation of the past, being an expression of the 'perfection of Beauty, [...] the Just glory of the Reformation'. ${ }^{43}$ The church of St. Mary Madgalene is Castleton's earliest parish church. The foundation dates from the Norman period. In 1592 Sir Walter Raleigh built a new church on the present site. Finished in 1601, the pile was described as 'very ruinous' ca. 1700. In 1714

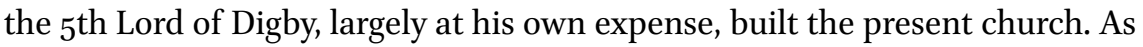
he told Alexander Pope, it features 'his own architecture': ${ }^{44}$ a remarkable example of English Gothic, clearly visible in the windows with Y-tracery and nave arcade. The façade has three gables, typical of West Country Gothic churches, as well as the four-centred arches to the doorways.

42 Dogett, "Willis Browne".

43 Lacy James, $A$ Sermon Preach'd at the Consecration of a Church in the Parish of Castle-Ton near Sherborne, Dorset 1715 (London, W[illiam] Taylor: 1715) 16. Colvin H.M., A Biographical Dictionary of British Architects, 1600-1840 (New Haven - London: 1995) 305.

44 Alexander Pope to Martha Blount, 22 June 1724 [?], in The Correspondence of Alexander Pope, ed. G. Sherburn, vol. II (Oxford: 1956) 239; cf. Colvin, Biographical Dictionary 304. 


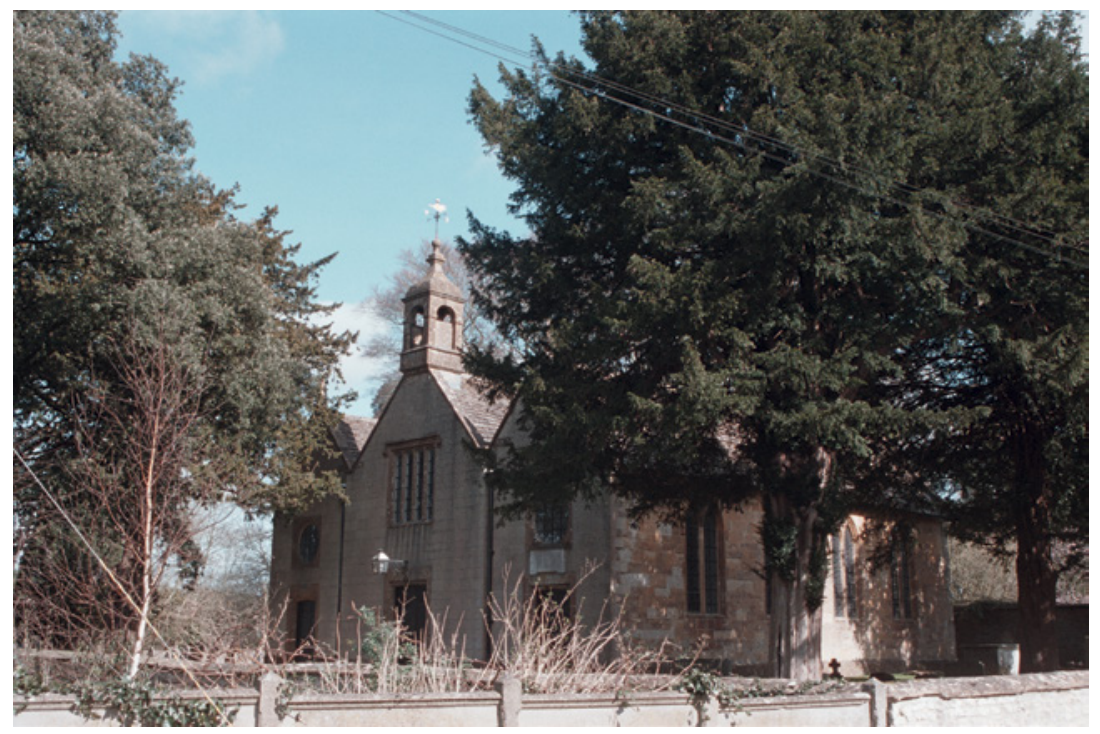

FIGURE 24.5 St Mary Magdalen's Church, Castleton Dorset (1715), William Digby IMAGE (C) HISTORIC ENGLAND ARCHIVE (NATIONAL HERITAGE, IMAGES OF ENGLAND. ALEC HOWARD)

Nicholas Hawksmoor, the main architect of the queen's 1711 official churchbuilding campaign, also was keen to use references to Gothic forms in his church buildings. In his youth, he had sketched a number of England's most important Gothic cathedrals and churches, including Bath Abbey and All Saints' Church in Northampton. His interest in the Gothic was further indulged during his career as an architect and by such publications as John Slezer's Theatrum Scotiae (1693) and Androuet du Cerceau's Livre d'Architecture, of which he owned a copy. In a letter to Dean Wilcocks from 18 March 1735, he testified to his love of English cathedrals and the Gothic style. Hawksmoor considered the Gothic to be an authentic Christian style. It was the first real architecture of the Christian area, since the earliest Christians had first built with fragments of antiquity:

After ages, whether Goths, Vandalls, Saracens or the Monks, afterwards, in Building Churches (no matter) partly out of necessity or partly humor. They made use of a different sort of Building with stones of less dimensions, and what they could easily transport or raise upon their fabricks, and sometimes patch'd up auckward Buildings, out of the Ruins of Old Magnificent Structures. This was what was afterwards calld Gothic. At first they built with large round pillars of five Diamr in height, and the Arches half round, wth Narrow Lights haveing half round heads, or 


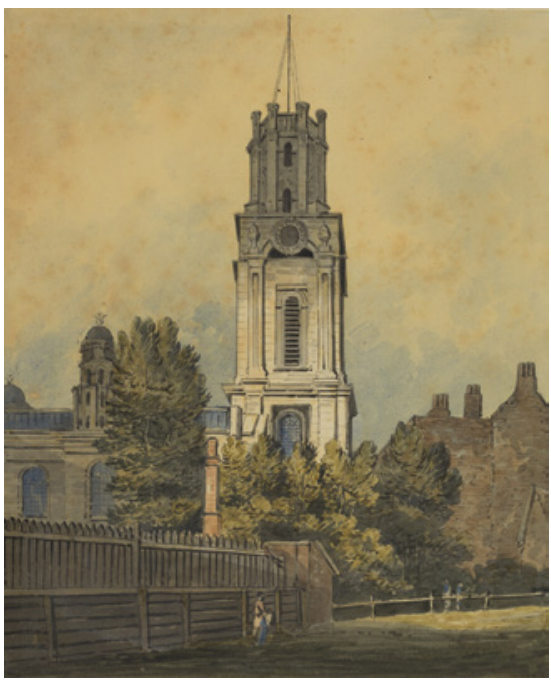

FIGURE 24.6

William Pearson, View of St George in the East, Stepney, Nicholas Hawksmoor (ca. 1815). Watercolour. London, Metropolitan Archives, Wakefield Collection IMAGE (C) LONDON, METROPOLITAN ARCHIVES

semicircular a top, and this is the most Antient style in the Gothick or Monastick manner, as they call'd it. ${ }^{45}$

This conception of the style was fundamental to his architectural practice, which commonly and easily entwined classical and Gothic forms, referring equally to the earliest Christian traditions. In his churches, such as St Georgein-the-East [Fig. 24.6], or his design for All Souls College Oxford, Gothic towers, pinnacles, tracery, and arches are presented in a classical and symmetrical way, while classical columns, obelisks, etc., function as medieval pinnacles and turrets. His Stepney churches (St George-in-the-East, St Anne's Limehouse) evoke national Gothic church traditions with their spires, lanterns, and buttresses.

\section{6}

\section{Conclusion}

The Reformation left the Church of England in a historical vacuum, reflected in the desolate and ruinous state of its architecture. While the Puritan factions supported the religious conviction that church buildings had to be 'cleansed' of idolatry, their (overzealous) efforts also swept away the monumental testimonies to and history of the English nation's zeal. Hence, the debates on church

45 Nicholas Hawksmoor to Dean Wilcocks, 18 March 1735, in Vaughan H. (ed.), Nicholas Hawksmoor. Rebuilding Ancient Wonders (New Haven: 2002) 62. 
building in England engaged with two issues. The first one was concerned with the church building as a dignified expression of religion situated between the extremes of iconoclastic parsimony and superstitious decorum. The second one was concerned with establishing the lineage between the Church of England and the earliest Christian settlements in England. While the first issue could be addressed in the traditional way of thinking about church architecture by means of biblical and early Christian referents, the second question necessitated the creation of a genuine English Christian tradition. The search for authenticity went hand in hand with a renewed interest for the national past, heritage, and roots. While the Saxon studies proved successful in the creation of an authentic early Christian tradition in England, they were much less useful in debates regarding church architecture, as none of their buildings survived. Nevertheless, under the impetus of the antiquarians - who were often Saxonists themselves - a genealogy of English Christianity was traced that ran from apostolic through Anglo-Saxon times to the years of the Reformation. Proof of this lineage was found in the history of religious foundations, longstanding traditions of tithes, and endowments linked to churches and cathedrals which still existed (albeit sometimes in a desolate or ruinous state). The church buildings through their monuments, glass windows, and inscriptions as well as through their evolution in architectural styles, were a visible testimony to the continuous zeal of the English. Hence, the antiquarians described the church buildings and their medieval architecture less in terms of the fallacy of idolatry than in terms of national piety and devotion. According to their descriptions church architecture was to be considered as a chronological evolution from Anglo-Saxon times through the Middle Ages and to the present day. Whereas idolatry had gradually crept in under 'popish' influences - which was at the time linked to later medieval architecture - the act of constructing monumental church buildings had remained an act of piety and devotion, while the iconoclastic movement of the Civil War was considered an attack on the national Church, resulting in sacrilege and schism. Even if this conviction was far from generally accepted, it certainly influenced the architectural decisions of supporters of a national Church based upon tradition. By means of architectural references to the recent past, they underlined the continuity of the English Christian tradition over the centuries to the present day, hence preserving the nation's zeal in times of danger of schism and heresy:

Our Church cannot have more genuine Sons than those, who by research into the primitive state of things, can refute the impudence of those abroad, who pretend to Antiquity; and can expose the ignorance of those 
at home, who affect Innovation. These Men can stand in the ways, and see the old paths, and are fit guides to those who are but of yesterday, and know nothing. ${ }^{46}$

\section{Bibliography}

Delbeke M. - Morel A.-F., "Metaphors in Action: Early Modern Church Buildings as Spaces of Knowledge", Architectural History 53, 10 (2010) 99-122.

Dugdale William, The History of St. Pauls Cathedral in London from Its Foundation Untill These Times: Extracted out of originall charters, records, leiger nooks, and other Manuscripts: beautified with sundry prospects of the church, figures of tombes and monuments (London, Thomas Warren: 1658).

Horsfall Turner O., Perceptions of Medieval Buildings in England, c.1640-c.1720 (London: 2009).

Parry G., The Trophies of Time: English Antiquarians of the Seventeenth Century (Oxford: 1995).

Quantin J.L., The Church of England and Christian Antiquity: The Construction of a Confessional Identity in the 17th Century (Oxford: 2009).

R.T., De Templis, a Treatise of Temples, Wherein is discovered the ancient manner of building, consecrating and adorning of Churches (London, $\mathrm{R}$ [ichard] Bishop: 1638).

Somner William, The Antiquities of Canterbury, or, a Survey of That Ancient Citie, with the Suburbs, and Cathedrall: Containing principally matters of antiquity in them all: collected chiefly from old manuscripts, lieger-bookes, and other like records, for the most part, never as yet printed (London, J[ohn] L[egat]: 1640).

Staveley Thomas, The History of Churches in England, Wherein is shewn, The Time, Means and Manner of Founding, Building, and Endowing of Churches, Both Cathedral and Rural (London: 1712).

van Eck C., British Architectural Theory 1540-1750: An Anthology of Texts (Aldershot: 2003).

van Eck C., Classical Rhetoric and the Visual Arts in Early Modern Europe (Cambridge: 2007).

46 White, "Life of Mr. Somner" 14. 